\title{
COVID-19 mortality in Istanbul in association with air pollution and socioeconomic status: an ecological study
}

\author{
Nilüfer Aykaç $^{1}$ (D) N Nilay Etiler ${ }^{2}$ (D) \\ Received: 6 July 2021 / Accepted: 15 September 2021 / Published online: 30 September 2021 \\ (C) The Author(s), under exclusive licence to Springer-Verlag GmbH Germany, part of Springer Nature 2021
}

\begin{abstract}
This study aims to reveal the relationship between the COVID-19 mortality indicators and socioeconomic status (SES) and air pollution. In this ecological study, the focus was put on the relationship between COVID-19 mortality and both air quality and socioeconomic status at the district level in Istanbul. The mortality variables of the study are the excess deaths due to the pandemic, the proportion of deaths due to the pandemic among all deaths, COVID-19 mortality rate (per 100,000), and the proportion of COVID-19 deaths among older people (above the age of 65). The daily air quality measurements of $\mathrm{PM}_{10}, \mathrm{SO}_{2}$, $\mathrm{NO}_{2}$, and $\mathrm{NO}_{\mathrm{x}}$ of the pre-pandemic term were included in the research to avoid bias due to decreasing traffic burden during the pandemic. Partial correlation was applied to analyze the relationship between air quality and mortality measures by controlling socioeconomic status, the percentage of the older population, and household size. Every 20\% deterioration in the SES stratum has contributed to a $4 \%$ increase in excess mortality at the district level. The elderly population ratio of over $10 \%$ in the districts was found to increase the COVID-19 deaths in the total population by $35 \%$ and the deaths in the population over 65 years old by $3 \%$. Average household size was correlated with COVID-19 deaths in the population over 65. A moderate correlation was found between the COVID-19 mortality rate per 100,000 population and $\mathrm{PM}_{10}, \mathrm{SO}_{2}$, and $\mathrm{NO}_{2}(r=0.413,0.421$, and 0.431 , respectively). Mortality during the COVID-19 pandemic in Istanbul is related to an interaction of socioeconomic characteristics and air pollution as an environmental issue.
\end{abstract}

Keywords SARS-CoV-2 $\cdot$ Social inequality $\cdot$ Ecological analysis $\cdot$ Air quality $\cdot$ Turkey

\section{Introduction}

The COVID-19 pandemic has caused the death of 3,930,496 as of June 30, 2021, according to official data of the World Health Organization (WHO Coronavirus Dashboard 2021). Findings indicate that the case fatality rate is $2 \%$ (Worldometer Coronavirus Pandemic 2021); however, many medical and social factors influence mortality.

Responsible Editor: Philippe Garrigues

Nilüfer Aykaç

niluferkongar@gmail.com

Nilay Etiler

nilayetiler@okan.edu.tr

1 Pulmonary Medicine Academic Hospital, Nuhkuyusu Cad. No. 94, Bağlarbaş1/Üsküdar/İstanbul, Turkey

2 Department of Public Health, Istanbul Okan University, Tuzla/ İstanbul, Turkey
Research has shown that exposure to air pollutants harms the respiratory system by causing free radical production in the organism and decreases the resistance to viral-bacterial infections (Ciencewicki and Jaspers 2007; Becker and Soukup 1999; Bourdrel et al. 2021; Urrutia-Pereira et al. 2020). In addition, it has been established that deaths due to COVID-19 are directly related to socioeconomic status and that diseases and deaths are more common among people with lower income (Wadhera et al. 2020; Clouston et al. 2021). On the other hand, obesity, tobacco use (Shastri et al. 2021), and indoor and outdoor air pollution, which increase the mortality of COVID-19, are also related to socioeconomic inequalities (Brandt et al. 2020; Guan et al. 2020; Khalatbari-Soltani et al. 2020). Indeed, obesity (Rubio Herrera and Bretón Lesmes 2021), tobacco use, and exposure to air pollutants (Martins et al. 2004) are significantly higher in lower socioeconomic groups. However, there are very limited studies investigating the effects of socioeconomic inequality and air pollution on COVID-19 mortality. In this study, pre-pandemic air pollution, which is an indication of the lung health of the 
population, is assumed to be in relationship with COVID-19 mortality. Socioeconomic status is the most important feature to consider in the analysis of this relationship. This study aims to reveal the relationship of COVID-19 deaths in Istanbul with air pollution by taking its relationship with socioeconomic status into consideration.

\section{Methods}

This is an ecological study that aims to reveal the relationship between COVID-19 deaths and air quality measures on a district basis in Istanbul. In this study, pre-pandemic air quality data indicated by particulate matter, sulfur dioxide, and nitrogen compound levels and the mortality rates during the pandemic have been analyzed on a district basis. In this analysis, the household size, socioeconomic status, and older population (over 65), which are factors highly correlated with COVID-19 deaths, have been analyzed as control variables.

\section{Mortality data}

Since the statistics of the Ministry of Health on the provincial distribution of COVID-19 deaths are not publicly accessible, the data of the Istanbul Metropolitan Municipality were used for the number of COVID-19 deaths in the districts of Istanbul. According to the death notification system updated in 2012 in Turkey, the responsible doctor for the treatment of the deceased or the municipal doctor, depending on whether or not the death took place in the hospital, issues a death certificate (Ministry of Health Death Notification System Circular (Art. 2) 2012). A copy of the document is sent to the cemetery, which is under the jurisdiction of the municipality, for the burial to be carried out. The information in the death notification system is being sent to the Turkish Statistical Institute (TurkStat). The causes of death are entered the system according to the ICD-10 classification, and a new cause of death has been added to the existing codes due to the pandemic, which is "Natural Death: Contagious Disease."

The database of the Istanbul Metropolitan Municipality Cemetery Directorate holds the death certificates which indicate the cause of death, date of death, and the residential information of the deceased. The total of deaths and the number of deaths due to infectious diseases for each district in 2020 have been taken from the database and processed for the study. The provincial death data for the last 5 years have been retrieved from TurkStat's public website for the calculation of excess data due to the pandemic. The annual average crude death rate has been calculated for the years between 2015 and 2019, and the result has been subtracted from all causes mortality rate of the year 2020 to obtain the excess death rate.

\section{Air quality data}

Istanbul, the most crowded city in Turkey, is also one of the biggest cities in the world. Istanbul, having 962 neighborhoods in its 39 districts, bears a significant traffic burden with many highways, three bridges over the Bosphorus, and marine traffic. Within the scope of the study, data from 26 fixed air quality monitoring stations belonging to the Air Quality Monitoring Center of Istanbul Metropolitan Municipality and 12 fixed air quality monitoring stations belonging to Marmara Clean Air Regional Directorate (MTMH) were used. The 6 months including the winter season before the pandemic were analyzed due to data quality issues. A lot of studies have been conducted that report the regression in air pollution due to protection measures during the pandemic such as physical movement restrictions and lockdowns (European Environment Agency 2020; Liu et al. 2021; Orak and Ozdemir 2021).

Pre-pandemic air pollution measurements were used, not the level of air pollution during the pandemic, due to the reduction of air pollution during the pandemic. Although it was aimed to use the air pollution data for the last 4 years prior to the pandemic, the data for the last 6 months was taken into account due to missing data reported by Istanbul Air Pollution Stations. In addition, since the long-term effect of air pollution on the respiratory and circulatory system is at the forefront during the COVID period, the pre-pandemic air pollution levels of the region are taken into account. In addition, since the long-term effect of air pollution on the respiratory and circulatory system is at the forefront during the COVID19 period, the pre-pandemic air pollution levels of the city are investigated for the study.

First, the daily values measured at each of the 37 stations between October 1, 2019, and March 31, 2020, have been calculated assuming to represent air quality in the districts. Then the list of neighborhoods in the $1-\mathrm{km}$ and $5-\mathrm{km}$ radius from where the stations are situated has been obtained from the IBB, Directorate of Geographic Information System. While there were 209 neighborhoods in the $1-\mathrm{km}$ radius, there were 561 neighborhoods in the $5-\mathrm{km}$ radius. There were 770 neighborhoods in total for which the air quality values were assessed. The air quality parameter values of the districts were taken as the arithmetic mean of the data on neighborhoods for which air quality was measured. One district (Çatalca) was excluded from the study because it was not situated near stations included in the study. Only $\mathrm{PM}_{10}$ was being measured in the Adalar district.

\section{Variables of the study}

The dependent variables of the study are (1) the proportion of excess deaths in 2020 compared to the average of the last 5 years (2015-2019); (2) the proportion of deaths due to 
COVID-19 among the total deaths; (3) number of deaths from COVID-19 per 100,000 population (COVID-19 mortality rate); and (4) the proportion of COVID-19 death among older people (over 65). The main independent variable is air quality, while the socioeconomic status, household size, the proportion of the old population (65+), and the population density are the control variables.

Since the concentrations of monitored air pollutants regress in the summer, the summer periods were excluded from the study, and the daily measurements of $\mathrm{PM}_{10}, \mathrm{SO}_{2}, \mathrm{NO}_{2}$, and $\mathrm{NO}_{\mathrm{x}}$ in the October 2019-March 2020 period were taken into consideration.

The socioeconomic status (SES) data were taken from research that revealed SES scores for neighborhoods, and the scores of the district were used as the median of the SES scores of the neighborhoods (IBB Open Data Portal).

All data analyzed within the scope of the study are shown in Table 1.

\section{Statistical analysis}

The descriptive statistics of the variables have been calculated in mean, median, standard deviation, and percentiles. The mortality indicators of the study were also calculated for each socioeconomic status stratum (richest, rich, middle, poor, and poorest) and that the calculation of crude mortality rate was applied for each SES stratum as shown in Table 1.

The relationship among socioeconomic status, population density, household size, and the elderly population ratio with COVID-19 mortality indicators was examined by multiple linear regression analysis. In the partial correlation analysis of the relationship between air pollutants and the COVID-19 mortality, the household size, proportion of the old population, and SES scores were included as control variables. SPSS 20.0 software package was used for statistical analysis.

\section{Limitations}

The most important limitation of our study is the numerical insufficiency of air quality monitoring stations in Istanbul, which hinders the representation of the whole city. Since air quality monitoring stations were established in areas with high levels of urban, industrial, and traffic density, it was impossible to evaluate air pollution for other residential areas. It can be concluded that the areas where the air quality is not being monitored have less air pollution. Since there is no air quality monitoring representing the district of Çatalca, it was excluded from the study.

\section{Results}

The districts of Istanbul are very heterogeneous in terms of population size and density, household size, the proportion of the elderly population, and socioeconomic status. While the population size of the districts is $396,473 \pm 204,591(16,033$ $957,398)$ people, the number of people per square kilometer is $16,874 \pm 22,385(48-134,934)$. Similarly, the household size is $3.34 \pm 0.45(2.47-4.32)$, the proportion of the over 65 age group is $8.52 \pm 4.29(3.55-19.70)$, and the socioeconomic status score is $39.42 \pm 19.30(12.5-87.50)$.

There is a similar heterogeneity among the districts in terms of air pollutants. While the mean $\mathrm{PM}_{10}$ concentration for 38 districts was $49.22 \pm 18.72(22-116)$, the $\mathrm{SO}_{2}, \mathrm{NO}_{2}$, and $\mathrm{NO}_{\mathrm{x}}$ concentrations for 37 districts were $9.35 \pm 6.55$ (2.6-27.4), $42.41 \pm 20.38$ (6.1-83.6), and $105.95 \pm 65.57$ (12.4370.20 ), respectively. Figure 1 shows the situation of air pollutants in the districts of Istanbul.

Table 2 shows the status of mortality indicators related to COVID-19 in 39 districts of Istanbul in 2020 and the situation across the districts and according to different socioeconomic levels.

Before examining the relationship between air pollution and COVID-19 mortality indicators, multivariate analysis was applied to determine the effects of SES scores, the proportion of the population over 65 , and urban and household density variables, which may have an impact on mortality. According to the results of the analysis for four mortality indicators, it has been found that each $20 \%$ increase in SES (quintile) led to a $4 \%$ increase in excess mortality in 2020. The share of COVID-19 deaths in total deaths increases by $10 \%$ for every additional individual in the household. The fact that the elderly population is over $10 \%$ increases the deaths due to COVID-19 in a population of 100,000 by $35 \%$, and among those over 65 , deaths due to COVID-19 increase by $3 \%$ (Table 3).

When the relationship between COVID-19 mortality indicators and concentration levels of air pollutants was examined, a moderate correlation was found between the COVID-19 mortality rate per 100,000 population and $\mathrm{PM}_{10}$, $\mathrm{SO}_{2}$, and $\mathrm{NO}_{2}(r=0.413,0.421$, and 0.431 , respectively $)$ (Table 4).

\section{Discussion}

This study is an ecological study investigating the relationship of COVID-19 deaths that occurred in Istanbul in 2020 with socioeconomic level and air pollution. As ecological studies analyze grouped or aggregated data (Porta 2008), the unit of analysis was taken as the districts of Istanbul. Ecological studies are inherently prone to the ecological fallacy that noncausal relationships are likely to be observed. On the other hand, it allows the analysis of the social factors that are clustered in groups or regions and that can be influential on the health of the individuals (Berkman and Kawachi 2004). In this study, ecological bias was tried to be minimized through 


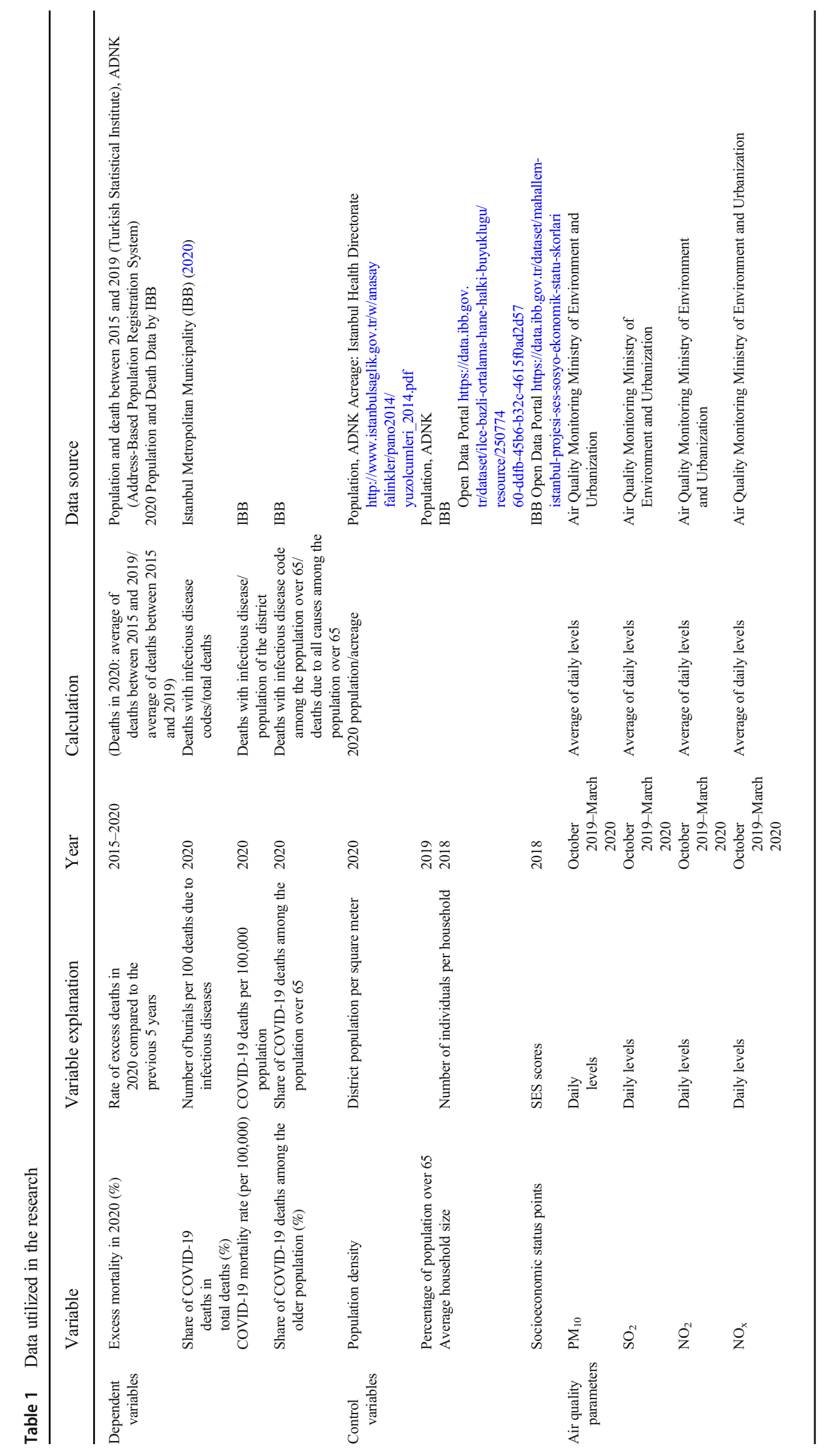



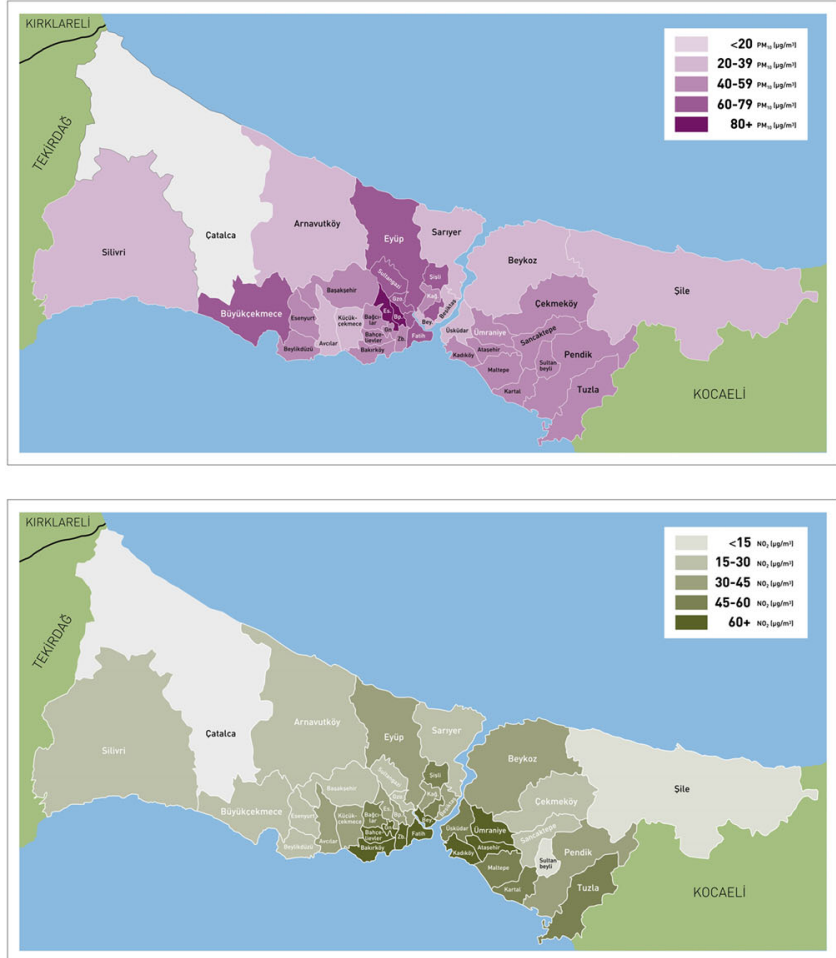

Fig. 1 The pre-pandemic outlook of air pollutants in Istanbul by district

multivariate analysis and inclusion of control variables in the analysis.

It is well known that both the severity and mortality of the coronavirus increase in correlation with age (Fang et al. 2020). Studies show that the mortality rate is 5 times higher for individuals over 80 . On the other hand, it is known that $66 \%$ of people aged 70 and over have comorbidity issues, and, therefore, the risk of being infected with the virus increases for this group (United Nations 2020; Thakur et al. 2021). Besides comorbidities, the physiological changes of aging and the decreased immune strength due to age also aggravate the risk and the burden of infection.

However, the negative effect of the virus on the elderly population cannot only be explained by biological processes. The socioeconomic levels of the elderly who moved on from their productive ages and are retired, especially those who
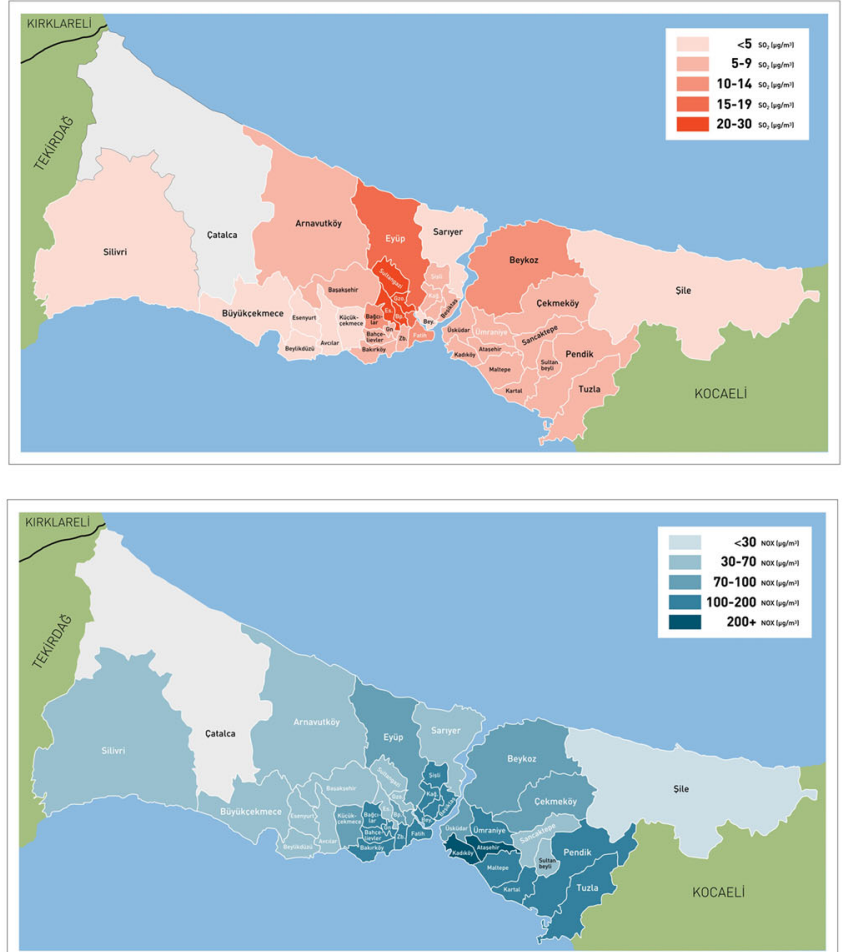

could not accumulate wealth during their productive ages, tend to be lower (UN Department of Economic and Social Affairs Programme on Ageing 2021). The mortality risk of the virus increases since chronic illnesses (Mair and Jani 2020) are more commonly seen among the groups with low socioeconomic levels and those chronic illnesses tend to remain unchecked for longer periods (Smith and Judd 2020; Hawkins et al. 2020).

In our study, the COVID-19 mortality rate increased by $35 \%$, and the mortality among the population aged over 65 by $3 \%$ in the districts with an elderly population of over $10 \%$ which confirms the increasing COVID-19 mortality rate with age. On the other hand, the positive correlation between the distribution of the elderly population in the districts of Istanbul and better socioeconomic status $(r=0.58)$ confirms the relationship between higher income and greater longevity. Lastly,

Table 2 COVID-19 deaths in Istanbul according to SES groups

\begin{tabular}{|c|c|c|c|c|c|c|}
\hline & & $\begin{array}{l}\text { Crude mortality } \\
\text { rate (per thousand) }\end{array}$ & $\begin{array}{l}\text { Excess } \\
\text { mortality } \\
\text { in } 2020(\%)\end{array}$ & $\begin{array}{l}\text { Share of COVID-19 } \\
\text { deaths in total deaths }(\%)\end{array}$ & $\begin{array}{l}\text { COVID-19 } \\
\text { mortality } \\
\text { rate (per } 100,000)\end{array}$ & $\begin{array}{l}\text { Share of COVID-19 } \\
\text { deaths among the } \\
\text { older population }(\%)\end{array}$ \\
\hline Istanbul & & 4.6 & 17.2 & 20.5 & 101.6 & 22.0 \\
\hline \multirow[t]{5}{*}{ Districts $(n=39) \quad$ SES groups } & Very rich & 8.4 & 2.8 & 14.2 & 119.0 & 13.0 \\
\hline & Rich & 5.8 & 11.0 & 18.9 & 110.6 & 17.7 \\
\hline & Middle & 4.6 & 17.3 & 22.8 & 105.0 & 21.4 \\
\hline & Poor & 3.6 & 22.1 & 25.0 & 88.8 & 24.0 \\
\hline & Very poor & 4.5 & 23.3 & 22.3 & 100.5 & 21.2 \\
\hline
\end{tabular}


Table 3 Sociodemographic variables influencing COVID-19 deaths $(n=38)$

Excess mortality Share of COVID-19 COVID-19 mortality

in $2020(\%)$ deaths in total deaths rate (per 100,000)

(\%)
Share of COVID-19

deaths among the total deaths of the population over 65

\begin{tabular}{|c|c|c|c|c|c|c|c|c|}
\hline \multicolumn{9}{|l|}{ Model summary } \\
\hline Adjusted $R^{2}$ & \multicolumn{2}{|l|}{0.62} & \multicolumn{2}{|l|}{0.76} & \multicolumn{2}{|l|}{0.38} & \multicolumn{2}{|l|}{0.79} \\
\hline \multirow[t]{2}{*}{$F$} & 16.34 & & 31.57 & & 6.73 & & 32.26 & \\
\hline & $B$ & $95 \% \mathrm{CI}$ & $B$ & $95 \% \mathrm{CI}$ & $B$ & $95 \% \mathrm{CI}$ & $B$ & $95 \% \mathrm{CI}$ \\
\hline Constant & NS & - & -14.37 & $-23.58-5.16$ & 119.06 & $27.191-210.93$ & -18.26 & $-27.34-9.17$ \\
\hline Population density (population per $\mathrm{km}^{2}$ ) & NS & - & NS & - & NS & - & NS & - \\
\hline Average household size & NS & - & 10.44 & $7.85-13.04$ & NS & - & 11.14 & $8.30-14.00$ \\
\hline District elderly population with a share more than $10 \%$ & NS & - & NS & - & 35.22 & $8.67-63.77$ & 3.01 & $1.01-6.73$ \\
\hline SES groups (in $20 \%$ percentiles) & 4.00 & $1.35-6.63$ & NS & - & NS & - & NS & - \\
\hline
\end{tabular}

the finding that the excess mortality in 2020 in Istanbul is independent of the ratio of the population over 65 points out the fact that those excess mortalities include the relatively young population and that social factors independent of the age are more effective on those excess deaths during the pandemic.

Although some have argued that the COVID-19 pandemic affects "everyone" without discrimination among people, just like other pandemics, the current pandemic had a more destructive effect on vulnerable groups. As Edgar Sydenstricker first revealed in his research in 1931 on the 1918 Spanish flu epidemic, infectious diseases are directly affected by inequalities between the social class. For this reason, the epidemics should be called "syndemics" rather than "pandemic" due to the significant impact of the social determinants of health (Bambra et al. 2020).

On the other hand, newer research has confirmed the findings of Sydenstricker. For example, during the 1918 Spanish flu, a mortality rate of 40 times higher was experienced in India compared to Denmark and 20 times more of a mortality rate was experienced in South America compared to Europe. Inequalities were existing within the countries as they did among the countries and regions. For example, the mortality rates were the highest among the working-class neighborhoods of Oslo in
Norway. A similar situation was observed during the H1N1 influenza pandemic in 2009. For example, the mortality rates in Mexico were higher than in those countries with higher income levels. And the mortality rates experienced in the poorest neighborhoods in Britain were at least three times higher than in the least poor neighborhoods (Bambra et al. 2020).

A relationship has been observed during the COVID-19 pandemic as it was also observed during the 1918 Spanish flu and the 2009 H1N1 influenza pandemic. For example, the infection rates in Spain during COVID-19 were seven times higher than the poorest areas of the Catalonia region. Similarly, the mortality rates among the residents of the most disadvantaged boroughs in New York City were significantly higher (Wadhera et al. 2020).

According to the data of the Turkish Statistical Institute, Istanbul had a $30.7 \%$ share in the gross domestic product (GDP) of Turkey in 2019. Similarly, Istanbul, with almost $\$ 10,000$ of income per capita, is at the top of the country's GDP per capita (Turkish Statistical Institute 2021a). However, while the Gini coefficient, which is an indicator of income inequality, was 0.395 (Turkish Statistical Institute 2019) in Turkey in 2019, the Gini coefficient was 0.428 in Istanbul, and it was the city with the highest income inequality in Turkey with a P80/P20 ratio of 7.8 (Turkish Statistical

Table 4 The relationship between air pollution levels and COVID-19 deaths on a district level

\begin{tabular}{|c|c|c|c|c|c|c|}
\hline Control variables & & & $\begin{array}{l}\text { Excess } \\
\text { mortality } \\
\text { in } 2020(\%)\end{array}$ & $\begin{array}{l}\text { Share of COVID-19 } \\
\text { deaths in total deaths }(\%)\end{array}$ & $\begin{array}{l}\text { COVID-19 mortality rate } \\
\text { (per } 100,000)\end{array}$ & $\begin{array}{l}\text { Share of COVID-19 } \\
\text { deaths among the } \\
\text { older population }(\%)\end{array}$ \\
\hline $\begin{array}{l}\text { Ratio of population over } 65 \\
\text { and SES scores and } \\
\text { household size }\end{array}$ & $\begin{array}{l}\mathrm{PM}_{10} \\
\mathrm{SO}_{2} \\
\mathrm{NO}_{2} \\
\mathrm{NO}_{\mathrm{x}}\end{array}$ & $\begin{array}{l}\text { Correlation coefficient } \\
\text { Correlation coefficient } \\
\text { Correlation coefficient } \\
\text { Correlation coefficient }\end{array}$ & $\begin{array}{l}0.210 \\
0.001 \\
-0.231 \\
-0.021\end{array}$ & $\begin{array}{l}0.257 \\
0.189 \\
0.245 \\
0.059\end{array}$ & $\begin{array}{l}0.413 * \\
0.422 * \\
0.431 * \\
0.127\end{array}$ & $\begin{array}{l}0.226 \\
0.234 \\
0.231 \\
0.074\end{array}$ \\
\hline
\end{tabular}

$* p<0.05$ 
Institute 2019). We found that the excess mortality rate due to COVID-19 in the districts of Istanbul with the highest income levels was $2.8 \%$, while the same rate was $23.3 \%$ in districts with worse socioeconomic levels. Nevertheless, we did not observe a significant difference in multivariate analysis of the COVID-19 mortality rate depending on the socioeconomic levels. However, every $20 \%$ regression in the socioeconomic status increased the excess mortality rate in 2020 by $4 \%$. In our opinion, the main reason for this difference is the inequality in access to health services. The reason is that health services were provided to COVID-19 patients entirely by government-funded healthcare providers and university hospitals rather than private hospitals. Except for the three peaks experienced in Istanbul, patients with health issues other than the symptoms of coronavirus were treated mostly by private hospitals. The high volume of COVID-19 cases treated in the public hospitals left patients experiencing non-COVID-19related health problems without a reliable public option. Private hospitals, which define and advertise themselves as "clean hospitals," worked to close this gap. Undoubtedly, this situation created a disadvantage in terms of accessing health services for people who cannot afford private healthcare providers for their non-COVID-19-related health problems.

In addition, the insufficiency of social support during the pandemic (International Monetary Fund 2021) led to an unwillingness for PCR tests and a tendency of underreporting those who were in contact with a positive case due to fear of losing income in cases of isolation or quarantine (Istanbul Medical Chamber 2021). For this reason, one cannot exclude the possibility that people living in poor and very poor areas did not receive a COVID-19 diagnosis, and some lost their lives without such a diagnosis.

SARS-CoV-2 is transmitted through aerosols and droplets produced when speaking, sneezing, or coughing, especially by infected people in a confined space (Chu et al. 2020; Kayalar et al. 2021). For this reason, infected people are 10 times more likely to spread the virus in their households compared to other scenarios (Lei et al. 2020). In addition, as expected, the increase in the number of individuals in the household increases the risk of transmission (Li et al. 2020). Madewell et al. showed that children, symptomatic cases, spouses, and high household size were effective factors in domestic transmission, which was $16.6 \%$ (Madewell et al. 2020). The size of the household is not only a factor depicting the microenvironment but also means there may be an employee in the household in regular contact with society. In our study, it was found that the household size aggravated the share of COVID-19 deaths and especially COVID-19 deaths among the population over 65 . This finding reveals why the population over 65 could not be properly protected, despite the restrictions applied to protect them. The virus spreads among many working-class families because the shutdown of businesses was limited.
The average household size in Turkey is 3.30 people in 2020. In Istanbul, the size is 3.27 (Turkish Statistical Institute 2021b). On the other hand, it is known that $12.3 \%$ of single-person households live below the poverty line, but this rate reaches $27.7 \%$ in households that consist of extended families. In other words, household size is also an indicator of socioeconomic status since it is negatively correlated with income level (Turkish Statistical Institute 2021a). WHO (2018) reported that household crowding is associated with infectious diseases including tuberculosis, other respiratory diseases, gastroenteritis, and diarrheal diseases. Therefore, the increased number of people in the households increases the indoor transmission of the virus and also indicates the effect of social determinants on COVID-19 deaths.

The WHO acknowledged indoor and outdoor pollution as significant causes of mortality even before the COVID-19 (WHO, 2016). However, the pandemic elevated the serious effect of air pollution on health because a positive correlation between COVID-19 mortality and air pollution has been observed. Indeed, a positive correlation between air quality and mortality was also observed during the SARS pandemic in 2003 (Cui et al. 2003).

Research indicates that air pollution increases the possibility of catching diseases by disrupting the body's natural defense against viruses and by playing a role in the transport of viruses (Kayalar et al. 2021; Cui et al. 2003). Another study reported that exposure to air pollutants increased the number of confirmed COVID-19 cases for all age groups (Isphording and Pestel 2021). Also, exposure to air pollution has been found to worsen the symptoms in those individuals with respiratory system infections, increasing the risks of hospitalization and death (Urrutia-Pereira et al. 2020). Similarly, it has been found that increased concentrations of $\mathrm{PM}_{2.5}$ and $\mathrm{PM}_{10}$ significantly increase the mortality of COVID-19 (Bianconi et al. 2020). Wu et al. reported that every $1-\mu / \mathrm{m}^{3}$ increase in $\mathrm{PM}_{2.5}$ per cubic meter leads to an $8 \%$ amplification in the COVID-19 mortality rate (Wu et al. 2020). In addition, it has been shown that long-term atmospheric exposure to $\mathrm{NO}_{2}$ accompanies increased COVID-19 deaths (Ogen 2020). On the other hand, in a study by Sharma et al., it was determined that the regressions in $\mathrm{PM}_{2.5}$ concentration during the lockdowns enforced to suppress the spread of the virus positively influenced COVID-19 mortality (Sharma and Balyan 2020). In line with the existing data, we found a moderate correlation between the COVID-19 mortality rate per 100,000 population and $\mathrm{PM}_{10}, \mathrm{SO}_{2}$, and $\mathrm{NO}_{2}$.

\section{Conclusion and suggestions}

SES groups, household size, and elderly population ratio were found to be associated with the COVID-19 mortality rate in Istanbul. When these sociodemographic variables were 
included in the determination of the relationship between urban air pollution and COVID-19 mortality, it was found that the COVID-19 mortality rate was correlated with the increase in $\mathrm{PM}_{10}, \mathrm{SO}_{2}$, and $\mathrm{NO}_{2}$ air pollutants. These results provide certain clues on how the COVID-19 pandemic has become a syndemic through the interaction with social inequalities and air pollution. We would like to emphasize a holistic approach for the alleviation of consequences of global pandemics similar to COVID-19 in a world where the gap in social inequalities is widening, the environmental reactions brought by the climate crisis are more widely felt, and public health systems are more neglected than before. This approach includes a wide spectrum of measures from ceasing the use of fossil fuels, which has been one of the important sources of many problems such as global climate change and urban air pollution, to other measures that will ensure social equality.

Acknowledgements We are grateful to our colleague, Assoc. Prof. Osman Elbek, M.D., for his critical reading, scientific contributions, and constructive comments; we are also thankful to Rukiye Aydın Türktaș and Ahmet Șengül from the Unit on Geographic Information System at Istanbul Metropolitan Municipality for calculations of the population living around the air quality stations in Istanbul and Ömer Erkmen for producing the maps.

Author contribution Both NA and NE were involved in the design of the study, management of data collection and data analysis, and manuscript preparation.

Data availability Not applicable.

\section{Declarations}

Ethics approval and consent to participate Not applicable.

Consent for publication Not applicable.

Competing interests The authors declare no competing interests.

\section{References}

Bambra C, Riordan R, Ford J, Matthews F (2020) The COVID-19 pandemic and health inequalities. J Epidemiol Community Health 74(11):964-968. https://www.ncbi.nlm.nih.gov/pmc/articles/ PMC7298201/. Accessed 30 June 2021

Becker S, Soukup JM (1999) Exposure to urban air particulates alters the macrophage-mediated inflammatory response to respiratory viral infection. J Toxicol Environ Health A 57(7):445-457. https://doi. org/10.1080/009841099157539

Berkman L, Kawachi I (2004) A historical framework for social epidemiology: social determinants of population health. In: Berkman L, Kawachi M (eds) Social Epidemiology, 2nd edn. Oxford University Press, Oxford, p 5

Bianconi V, Bronzo P, Banach M, Sahebkar A, Mannarino MR, Pirro M (2020) Particulate matter pollution and the COVID-19 outbreak: results from Italian regions and provinces. Arch Med Sci 16(5): 985-992. https://doi.org/10.5114/aoms.2020.95336

Bourdrel T, Annesi-Maesano I, Alahmad B, Maesano CN, Bind MA (2021) The impact of outdoor air pollution on COVID-19: a review of evidence from in vitro, animal, and human studies. Eur Respir Rev 30(159):200242. https://doi.org/10.1183/16000617.0242-202

Brandt EB, Beck AF, Mersha TB (2020) Air pollution, racial disparities, and COVID-19 mortality. J Allergy Clin Immunol 146(1):61-63. https://doi.org/10.1016/j.jaci.2020.04.035

Chu DK, Akl EA, Duda S, Solo K, Yaacoub S, Schünemann HJ, Chu DK, Akl EA, el-harakeh A, Bognanni A, Lotfi T, Loeb M, Hajizadeh A, Bak A, Izcovich A, Cuello-Garcia CA, Chen C, Harris DJ, Borowiack E, Chamseddine F, Schünemann F, Morgano GP, Muti Schünemann GEU, Chen G, Zhao H, Neumann I, Chan J, Khabsa J, Hneiny L, Harrison L, Smith M, Rizk N, Giorgi Rossi P, AbiHanna P, el-khoury R, Stalteri R, Baldeh T, Piggott T, Zhang Y, Saad Z, Khamis A, Reinap M, Duda S, Solo K, Yaacoub S, Schünemann HJ (2020) Physical distancing, face masks, and eye protection to prevent person-to-person transmission of SARS-CoV-2 and COVID-19: a systematic review and meta-analysis. Lancet 395:1973-1987. https://doi.org/10.1016/ S0140-6736(20)31142-9

Ciencewicki J, Jaspers I (2007) Air pollution and respiratory viral infection. Inhal Toxicol 19:1135-1146

Clouston SAP, Natale G, Link BG (2021) Socioeconomic inequalities in the spread of coronavirus-19 in the United States: an examination of the emergence of social inequalities. Soc Sci Med 268:113554. https://doi.org/10.1016/j.socscimed.2020.11355

Cui Y, Zhang ZF, Froines J, Zhao J, Wang H, Yu SZ (2003) Air pollution and case fatality of SARS in the People's Republic of China: an ecologic study. Environ Health 2:1

European Environment Agency (2020) Air quality in Europe Report. https://www.eea.europa.eu/publications/air-quality-ineurope-2020-report. Accessed 30 June 2021

Fang X, Li S, Yu H, Wang P, Zhang Y, Chen Z, Li Y, Cheng L, Li W, Jia H, Ma X (2020) Epidemiological, comorbidity factors with severity and prognosis of COVID-19: a systematic review and meta-analysis. Aging (Albany NY) 12(13):12493-12503. https://doi.org/10. 18632/aging. 103579

Guan WJ, Liang W, Zhao Y, Liang H, Chen Z (2020) Comorbidity and its impact on 1590 patients with COVID-19 in China: a nationwide analysis. Eur Respir J 55(5):2000547. https://doi.org/10.1183/ 13993003.00547-2020

Hawkins RB, Charles EJ, Mehaffey JH (2020) Socio-economic status and COVID-19-related cases and fatalities. Public Health 189: 129-134. https://doi.org/10.1016/j.puhe.2020.09.016

International Monetary Fund (2021) Fiscal monitor database of country fiscal measures in response to the COVID-19 pandemic. https:// www.imf.org/en/Topics/imf-and-covid19/Fiscal-Policies-Databasein-Response-to-COVID-19. Accessed 1 Aug 2021

Isphording IE, Pestel N (2021) Pandemic meets pollution: poor air quality increases deaths by COVID-19. J Environ Econ Manag 108: 102448. https://doi.org/10.1016/j.jeem.2021.102448

Istanbul Medical Chamber (2021) Filiation activities during the coronavirus epidemic in Istanbul. https://www.istabip.org.tr/site_icerik/ 2021/ocak/filyasyon_rapor.pdf. Accessed 30 June 2021

Istanbul Metropolitan Municipality (IBB) (2020) Open data portal. My Neighborhood Istanbul Project (SES (socioeconomic status) scores). https://data.ibb.gov.tr/dataset/mahallem-istanbul-projesises-sosyo-ekonomik-statu-skorlari. Accessed 30 June 2021

Kayalar Ö, Arı A, Babuççu G, Konyalılar N, Doğan Ö, Can F, Șahin ÜA, Gaga EO, Levent Kuzu S, Arı PE, Odabașı M, Tașdemir Y, Sıddık Cindoruk S, Esen F, Sakın E, Çalıșkan B, Tecer LH, Fıçıcı M, Altın A, Onat B, Ayvaz C, Uzun B, Saral A, Döğeroğlu T, Malkoç S, Üzmez ÖÖ, Kunt F, Aydın S, Kara M, Yaman B, Doğan G, Olgun B, Dokumacı EN, Güllü G, Uzunpınar ES, Bayram H (2021) 
Existence of SARS-CoV-2 RNA on ambient particulate matter samples: a nationwide study in Turkey. Sci Total Environ 789:147976. https://doi.org/10.1016/j.scitotenv.2021.147976

Khalatbari-Soltani S, Cumming RC, Delpierre C, Kelly-Irving M (2020) Importance of collecting data on socioeconomic determinants from the early stage of the COVID-19 outbreak onwards. J Epidemiol Community Health 74:620-623

Lei H, Xu X, Xiao S, Wu X, Shu Y (2020) Household transmission of COVID-19-a systematic review and meta-analysis. J Inf Secur 81(6):979-997. https://doi.org/10.1016/j.jinf.2020.08.033

Li J, Gong X, Wang Z, Chen R, Li T, Zeng D, Li M (2020) Clinical features of familial clustering in patients infected with 2019 novel coronavirus in Wuhan, China. Virus Res 286:198043. https://doi. org/10.1016/j.virusres.2020.198043

Liu F, Wang M, Zheng M (2021) Effects of COVID-19 lockdown on global air quality and health. Sci Total Environ 755(Pt 1):142533. https://doi.org/10.1016/j.scitotenv.2020.142533

Madewell ZJ, Yang Y, Longini IM, Halloran ME, Dean NE (2020) Household transmission of SARS-CoV-2: a systematic review and meta-analysis. JAMA Netw Open 3(12):e2031756

Mair FS, Jani BD (2020) Emerging trends and future research on the role of socioeconomic status in chronic illness and multimorbidity. Lancet Public Health 5(3):128-129. https://doi.org/10.1016/ S2468-2667(20)30001-3

Martins MC, Fatigati FL, Véspoli TC, Martins LC, Pereira LA, Martins MA, Saldiva PH, Braga AL (2004) Influence of socioeconomic conditions on air pollution adverse health effects in elderly people: an analysis of six regions in São Paulo, Brazil. J Epidemiol Community Health 58(1):41-46. https://doi.org/10.1136/jech.58.1. 41

Ministry of Health Death Notification System Circular (2012)https:// www.saglik.gov.tr/TR\%2C11167/olum-bildirim-sistemiobsgenelgesi.html. Accessed 30 June 2021

Ogen Y (2020) Assessing nitrogen dioxide $\left(\mathrm{NO}_{2}\right)$ levels as a contributing factor to coronavirus (COVID-19) fatality. Sci Total Environ 726: 138605

Orak NH, Ozdemir O (2021) The impacts of COVID-19 lockdown on PM10 and SO2 concentrations and association with human mobility across Turkey. Environ Res 197:111018. https://doi.org/10.1016/j. envres.2021.111018

Porta M (2008) A dictionary of epidemiology, 5th edn. Oxford Press, Oxford

Rubio Herrera MA, Bretón Lesmes I (2021) Obesity in the COVID era: a global health challenge. Endocrinol Diabetes Nutr 68(2):123-129. https://doi.org/10.1016/j.endinu.2020.10.001

Sharma AK, Balyan P (2020) Air pollution and COVID-19: is the connect worth its weight? Indian J Public Health 64(Supplement):132134. https://doi.org/10.4103/ijph.IJPH_466_20

Shastri MD, Shukla SD, Chong WC, KC R, Dua K, Patel RP, Peterson GM, O'Toole RF (2021) Smoking and COVID-19: what we know so far. Respir Med 176:106237. https://doi.org/10.1016/j.rmed. 2020.106237

Smith JA, Judd J (2020) COVID-19: Vulnerability and the power of privilege in a pandemic. Health Promot J Austr 31(2):158-160. https://doi.org/10.1002/hpja.333
Thakur B, Dubey P, Benitez J, Torres JP, Reddy S, Shokar N, Aung K, Mukherjee D, Dwivedi AK (2021) A systematic review and metaanalysis of geographic differences in comorbidities and associated severity and mortality among individuals with COVID-19. Sci Rep 11:8562. https://doi.org/10.1038/s41598-021-88130-w

Turkish Statistical Institute (2019) Income and living conditions survey, 2019 Newsletter. https://data.tuik.gov.tr/Bulten/Index?p=Gelir-veYasam-Kosullari-Arastirmasi-2019-33820. Accessed 30 June 2021

Turkish Statistical Institute (2021a) Provincial gross domestic product 2019. https://data.tuik.gov.tr/Bulten/Index?p=Gross-DomesticProduct-by-Provinces-2019-33663\#: :text=T\%C3\%9C\%C4\% B0K $\% 20$ Kurumsal\&text $=\% \mathrm{C} 4 \% \mathrm{~B} 01 \% 20 \mathrm{~d} \% \mathrm{C} 3 \% \mathrm{BCzeyinde} \%$ 20 cari $\% 20$ fiyatlarla $\% 20 \mathrm{GSYH}, 1 \% 20$ pay $\% 20$ ile $\% 20 \% \mathrm{C} 4 \%$ B0zmir\%20izled. Accessed 30 June 2021

Turkish Statistical Institute (2021b) Statistics on family, 2020. https:// data.tuik.gov.tr/Bulten/Index?p=Istatistiklerle-Aile-2020-37251\#: $\sim:$ text=Ortalama $\% 20$ hanehalk $\%$ C4\% B $\% 20 \mathrm{~b} \% \mathrm{C} 3 \% \mathrm{BCy} \% \mathrm{C} 3 \%$ $\mathrm{BCk} 1 \% \mathrm{C} 3 \% \mathrm{BC} \% \mathrm{C} 4 \% 9 \mathrm{~F} \% \mathrm{C} 3 \% \mathrm{BC} \% 203 \% 2 \mathrm{C} 30,3 \% 2 \mathrm{C} 30 \%$ $20 \mathrm{ki} \% \mathrm{C} 5 \% 9$ Fiye $\% 20 \mathrm{~d} \% \mathrm{C} 3 \% \mathrm{BC} \% \mathrm{C} 5 \% 9 \mathrm{Ft} \% \mathrm{C} 3 \% \mathrm{BC} \% \mathrm{C} 4 \% 9 \mathrm{~F} \%$ $\mathrm{C} 3 \% \mathrm{BC} \% 20 \mathrm{~g} \% \mathrm{C} 3 \% \mathrm{~B} 6 \mathrm{r} \% \mathrm{C} 3 \% \mathrm{BCld} \% \mathrm{C} 3 \% \mathrm{BC}$. Accessed 30 June 2021

UN Department of Economic and Social Affairs Programme on Ageing. Income poverty in old age: an emerging development priority. https://www.un.org/esa/socdev/ageing/documents/ PovertyIssuePaperAgeing.pdf. Accessed 30 June 2021

United Nations (2020) Policy brief: the impact of COVID-19 on older persons. https://unsdg.un.org/sites/default/files/2020-05/PolicyBrief-The-Impact-of-COVID-19-on-Older-Persons.pdf. Accessed 30 June 2021

Urrutia-Pereira M, Mello-da-Silva CA, Solé D (2020) COVID-19 and air pollution: a dangerous association? Allergol Immunopathol (Madr) 48(5):496-499

Wadhera RK, Wadhera P, Gaba P, Figueroa JF, Joynt Maddox KE, Yeh RW, Shen C (2020) Variation in COVID-19 hospitalizations and deaths across New York City boroughs. JAMA 323(21):21922195. https://doi.org/10.1001/jama.2020.7197

WHO (2016) Ambient air pollution: a global assessment of exposure and burden of disease. https://www.who.int/publications/i/item/ 9789241511353. Accessed 30 June 2021

WHO (2018) WHO housing and health guidelines. Geneva: World Health Organization; 2018. License: CC BY-NC-SA 3.0 IGO.

WHO Coronavirus Dashboard. https://covid19.who.int/. Accessed 30 June 2021

Worldometer Coronavirus Pandemic. https://www.worldometers.info/ coronavirus. Accessed 24 Sept 2021

Wu X, Nethery R, Sabath B, Braun D, Dominici F (2020) Exposure to air pollution and COVID-19 mortality in the United States. medRxiv. https://doi.org/10.1101/2020.04.05.20054502

Publisher's note Springer Nature remains neutral with regard to jurisdictional claims in published maps and institutional affiliations. 